\title{
Hydrological Drought Analysis of Karkheh River Basin in Iran Using Variable Threshold Level Method
}

\author{
MAHSHID KARIMI and KAKA SHAHEDI \\ Department of Watershed Management, Sari Agricultural \\ Sciences and Natural Resources University, Sari, Iran.
}

http://dx.doi.org/10.12944/CWE.8.3.11

(Received: November 05, 2013; Accepted: December 17, 2013)

\begin{abstract}
Drought is an important phenomenon in recent years which caused a lot of problems for most of areas in Iran. Drought lead to water scarcity for people and this problem becomes one of the important challenges for the country. Karkheh River basin is one of the considerable water resources field in Iran and it is located in west parts of Iran. Current paper tries to take one step ahead toward scientific and practical drought management in Karkheh basin by analyzing hydrological drought. In this paper using daily discharge time series of 13 hydrometric stations which are located in the basin and also applying threshold level method, dry periods were extracted and results were analyzed. Results showed that the most volume and the most duration of drought in threshold level of 70\% mostly happened within 1998-2000 and 2006-2008. Also the results of the frequency analysis of drought parameters indicted that for maximum deficit volume series Weibull distribution and Generalized Pareto Distribution (GP) in accordance with $77 \%$ of stations and for maximum duration series, GP distribution in accordance with $54 \%$ of stations had the most consistency. Based on this consistency, return period of droughts were also computed and the possibility of drought predictions in future was determined.
\end{abstract}

Key words: Hydrological Drought, Variable Threshold Level, Karkheh,

Deficit Volume, Drought duration.

\section{INTRODUCTION}

Drought event is the most critical environmental phenomenon that has special hydrological and meteorological characteristics in each area (Samiei et al., 2006)'. In one general explanation drought means unnatural scarcity of rainfall in long-term periods. This introduction is meaningful when the scarcity leads to lack of moisture in soil, decrease in water flow and interruption of human activity, plants and animal's life (Khazaei et al., 2003)2. Different types of drought are meteorological, hydrological, agricultural and socio-economic (Hisdal and Tallaksen 20003; Mishra and Singh 20104; Van Loon and Van Lanen

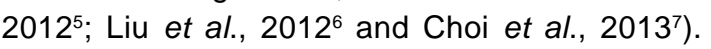
Among these different types of drought, investigation of the hydrological drought is too important due to dependence of most of the activities (including industrial, water and power plants) to surface water resources (Vasilides et al., $2011)^{8}$. In this research hydrological drought is investigated. One of the most common quantitative explanations of hydrological drought is based on introducing a threshold level which less than that for river flow is considered as hydrological drought (Tallaksen 2000) ${ }^{9}$.

Low amount of rainfall, its improper distribution and also occurred droughts in recent years, caused great problems in the field of water resources for most of the areas located in Iran. One of these areas which are influenced by drought is Karkheh river basin. According to the location of this basin in some provinces and also its important role as a large water resource for wide areas of the 
country, drought can cause socio-economic problems. The results of hydrological drought's analysis can be useful for proper water resources management, better planning for water supply and demand and applying every kind of program and consistent practices regarding intensity and duration of droughts.

\section{MATERIALS AND METHODS}

\section{Study area}

Karkheh River basin is located in west part of Iran. This basin is located between 46 06-49 10 E longitudes and 30 58-35 $04 \mathrm{~N}$ latitude. To investigate the hydrological drought, daily discharges of hydrometric stations located in this basin were obtained from Water Resources Management Organization of Iran called Tamab. According to the investigations, 13 hydrometric stations which are located on the main tributaries in this river basin were selected. Maximum and minimum length of existing data for these stations was 54 and 20 years period, respectively. Figure 1 shows the location of study area and hydrometric stations and Table 1 illustrates the characteristics of the stations.

\section{The threshold level method}

Threshold level method has been one of the most practical methods to analyze drought and water scarcity. In another word, this method is the base of the explanation of drought characteristics and water scarcity. In this method if the amounts of the discharges are less than a specific amount of threshold level, drought and water scarcity will be happened (Bonacci 1993) ${ }^{10}$. It is possible to select threshold level with different methods and this selection is related to the kind and water scarcity condition of study area (Zelenhasic and Salvai 1987) ${ }^{11}$. In this research proper threshold level for extracting hydrological drought periods was chosen using flow duration curve which shows the relationship between daily discharges and the probability of their occurrence $P(X \geq x)$. Threshold level can be defined as $70-95 \%$ of daily flow duration curve (Hisdal et al., (2002) ${ }^{12},(2004)^{13}$, Engeland et al., (2004) ${ }^{14}$, Andreadis et al., (2005) ${ }^{16}$, Fleig et al., (2006) ${ }^{16}$,Tallaksen et al., 200917; Wong et al., (2011) ${ }^{18}$ and Van Loon and Van Lanen 2012) and in this study $70 \%$ level was chosen. Threshold level also can be considered constant or variable during a year as changes seasonally, monthly or weekly. In constant threshold level method a flow duration curve for total statistical period is drawn and for total time series of discharge just one threshold level is considered. But in a variable threshold level method, a flow duration curve for each month is drawn separately and for each month a threshold level is determined. This matter leads to an increasing in the accuracy of flow deficit investigation during months with low and high discharges and at last the prediction of drought for future years in comparison with constant threshold level method would be more accurate and proper.

Duration of suite (drought duration $\mathrm{d}_{\mathrm{i}}$ ) and its aggregation (deficit volume or severity $\mathrm{S}_{\mathrm{i}}$ ) are suggested as point drought parameters (Vrochidou et al., 2013 ${ }^{19}$; Giuntoli et al., 2013 ${ }^{20}$ ). Considering daily discharge time series $\left(Q_{k}\right)$, it is possible to present the relationship between the parameters as:

$$
\begin{aligned}
& D_{Q}=\left\{\begin{array}{ccc}
Q_{2}-Q_{X} & \text { if } Q_{X}<Q_{2} \\
0 & \text { if } & Q_{X} \geq Q_{2}
\end{array}\right\} \\
& S_{i}=86.4 \sum_{j=1}^{d i} D_{Q}
\end{aligned}
$$

Where $D_{Q}$ means daily discharge deficit $\left(\mathrm{m}^{3} / \mathrm{s}\right), \mathrm{S}_{i}$ is deficit volume of drought $\mathrm{i}\left(1000 \mathrm{~m}^{3}\right)$ and 86.4 is the transformation coefficient that is related to the transformation of time scale. Hydrological drought analysis using daily time series faces with two problems. First problem is dependency between droughts and other one is existence of minor droughts during a long-term period drought in which the amount of flow for a short-term period exceeds the chosen threshold level. This issue results in the separation of a great drought to small and dependent ones during a longterm drought To solve this problem some pooling procedures must be applied. Pooling procedures include Moving Average (MA), Sequent Peak Algorithm (SPA) and the Inter event Time Criterion (IT- Criterion) (Tallaksen et al., 199721; Hisdal et al., 2004; Fleig 200422; Fleig et al., 2006; Pandy et al., $2008)^{23}$. In the last method for removing minor droughts and pooling dependent ones, some coefficients like $\alpha \pm, d_{\min }$ and $t_{c}$ are used. $\alpha$ is such a 
coefficient that is used for removing minor droughts. If in a drought deficit volume becomes less than the product of $\alpha$ coefficient and maximum volume multiplication $\left(\mathrm{S}_{\mathrm{i}}<\alpha \mathrm{S}_{\max }\right)$, it will be removed and its amount is usually considered between 0.005-0.01. is the minimum time interval which the minor droughts with the equal duration or less than that would be removed ( $d i \leq d_{\min }$ ) and is usually considered less than 5 days. is named critical time and if two dependent drought phenomenon occur with time interval $\left(t_{i}<t_{c}\right)$ they will be pooled. In conditions, duration and deficit volume would be pooled $\left(\mathrm{S}_{\text {pool, }} \mathrm{d}_{\text {pool }}\right)$ and they were computed as:

$$
\begin{aligned}
& d_{\text {pool }}=d_{i}+d_{i+1}+t_{i} \\
& S_{\text {pool }}=S_{i}+S_{i+1}
\end{aligned}
$$

Finally in the current research for excluding minor droughts and pooling dependent ones IC method was applied. According to Fleig (2004) amount of á is equal to 0.005 and $d_{\min }$ and $t_{c}$ are considered 2 and 5 days, respectively. For frequency analysis (shiau 2006 ${ }^{24}$ ) Easyfit software was used. Probability distributions such as Gamma, Weibull, Log-Normal, Johnson, Gumbel and Generalized Pareto were evaluated to fit to annual maximum series of deficit volume and drought duration. Then the best distributions were selected based on Chisquare test (Zelenhasic and Salvai 1987). According to probable occurrence derived from probability distribution $\mathrm{F}_{\mathrm{t}}(\mathrm{x})$, different return periods of drought parameters were computed as:

$$
T_{(x)}=\frac{1}{F_{i}(X)}
$$

\section{RESULTS}

Number of all occurred droughts in all stations is 1616 events. The largest number of drought occurrence is belong to station 21-169 which equals 206 cases and the least is related to station 21-157 equal to 54 cases (Fig 2).

Results of the variable threshold level method showed that in 1954-1967 Period, hydrological drought was observed in most of the stations. In 1968, 1974, 1982, 1987, 1992, 1994 and 1995 hydrological droughts were not occurred in most of the stations and the Karkheh River basin faces with wet years at these years. During 19962008 drought was happened in all stations (Fig 3).

Average of deficit volumes and drought duration are $9.058 \mathrm{Mm}^{3}$ and 36 days, respectively. The largest and lowest values of deficit volume are related to stations 21-411 and 21-163 and are 98.35 and $0.72 \mathrm{Mm}^{3}$, respectively. For drought duration, the largest and lowest values are 52 and 26 days which belong to stations 21-411 and 21-167, respectively. Figure 4 and Figure 5 show average deficit volume and average drought duration in all

Table 1: Characteristics of selected hydrometric stations in Karkheh River basin

\begin{tabular}{lccccccc}
\hline Code & Hyd. St. & Longitude & $\begin{array}{c}\text { Latitude } \\
(\mathbf{m})\end{array}$ & $\begin{array}{c}\text { Height } \\
\left(\mathbf{m}^{2}\right)\end{array}$ & Area & River & $\begin{array}{c}\text { Years } \\
\text { with data }\end{array}$ \\
\hline $21-105$ & Sangsurakh & $48^{\circ} 23^{\prime}$ & $34^{\circ} 32^{\prime}$ & 1800 & 320 & Gamasiab & $1969-2008$ \\
$21-109$ & Firuzabad & $47^{\circ} 72^{\prime}$ & $34^{\circ} 212^{\prime}$ & 1450 & 845.6 & Toserkan & $1954-2008$ \\
$21-115$ & Doab & $47^{\circ} 54^{\prime}$ & $34^{\circ} 222^{\prime}$ & 1410 & 7769.3 & Gamasiab & $1969-2008$ \\
$21-127$ & Polechehr & $47^{\circ} 26^{\prime}$ & $34^{\circ} 212^{\prime}$ & 1280 & 10867.5 & Gamasiab & $1954-2008$ \\
$21-131$ & Khersabad & $46^{\circ} 44^{\prime}$ & $34^{\circ} 312^{\prime}$ & 1320 & 1439.2 & Abmerk & $1974-2008$ \\
$21-133$ & Doabmerk & $46^{\circ} 47^{\prime}$ & $34^{\circ} 332^{\prime}$ & 1290 & 1244.7 & Gharesou & $1954-2008$ \\
$21-143$ & Ghurbaghestan & $47^{\circ} 15^{\prime}$ & $34^{\circ} 142^{\prime}$ & 1230 & 5312.9 & Gharesou & $1956-2008$ \\
$21-157$ & Dartoot & $46^{\circ} 41^{\prime}$ & $33^{\circ} 452^{\prime}$ & 950 & 2589.3 & Abchenareh 1988-2008 \\
$21-163$ & Tang-siab & $47^{\circ} 12^{\prime}$ & $33^{\circ} 232^{\prime}$ & 880 & 565 & Darehdozdan 1974-2008 \\
$21-167$ & Dehno & $48^{\circ} 47^{\prime}$ & $33^{\circ} 312^{\prime}$ & 1770 & 265.6 & Horrood & $1988-2008$ \\
$21-169$ & Kakareza & $48^{\circ} 16^{\prime}$ & $34^{\circ} 432^{\prime}$ & 1530 & 1145 & Horrood & $1355-2008$ \\
$21-171$ & Sarabseyed Ali & $48^{\circ} 13^{\prime}$ & $33^{\circ} 482^{\prime}$ & 1520 & 776.6 & Doabaleshtar 1954-2008 \\
$21-411$ & Seymareh & $47^{\circ} 26$ & $33^{\circ} 112^{\prime}$ & 530 & $28954 / 3$ & Seimareh & $1982-2008$ \\
\hline
\end{tabular}


stations, respectively.

The most proper probability distributions for annual maximum series of deficit volume and drought duration were determined in each station (Table 2).

Then there are two kinds of drought analysis for each station including one is based on deficit volume series and another is based on drought duration. After determination of the best distribution, droughts' return period was obtained using Eq. 5 (Table 3).

\section{DISCUSSION}

According to the results of variable threshold level method in this research, there was drought in most of the years in all stations. In fact based on threshold level explanation, drought was occurred in most of the years even for a short period. As observed the most and the least deficit volumes

Table 2: The most suitable probability distributions of drought time series

\begin{tabular}{lccc}
\hline Code & Station & \multicolumn{2}{c}{ Suitable distribution for } \\
\cline { 3 - 4 } & & Deficit volume & Duration \\
\hline $21-105$ & Sangsurakh & Weibull & Johnson \\
$21-109$ & Firuzabad & Weibull & Gamma \\
$21-115$ & Doab & Gamma & Gamma \\
$21-127$ & Polechehr & Gen. pareto & Gen. pareto \\
$21-131$ & Khersabad & Gen. pareto & Gen. pareto \\
$21-133$ & Doabmerk & Gen. pareto & Gen. pareto \\
$21-143$ & Ghurbaghestan & Gamma & Gen. pareto \\
$21-157$ & Daroot & Gen. pareto & Johnson \\
$21-163$ & Tang-siab & Gamma & Gen. pareto \\
$21-167$ & Dehno & Weibull & Gamma \\
$21-169$ & Kakareza & Weibull & Johnson \\
$21-171$ & Sarabseyed Ali & Weibull & Johnson \\
$21-411$ & Seymareh & Gen. pareto & Gen. pareto \\
\hline
\end{tabular}

Table 3: Return period of the most severe and longest drought events

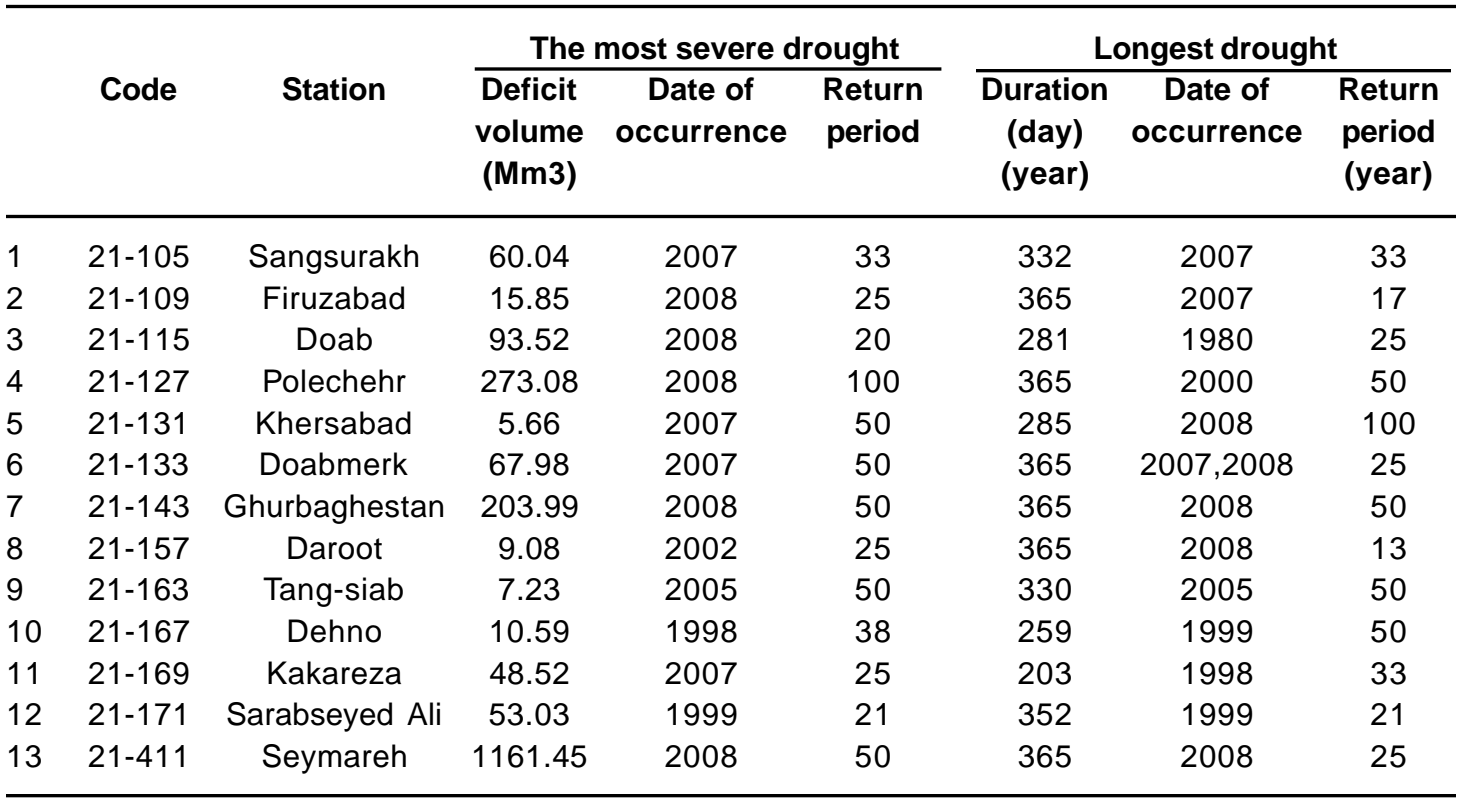




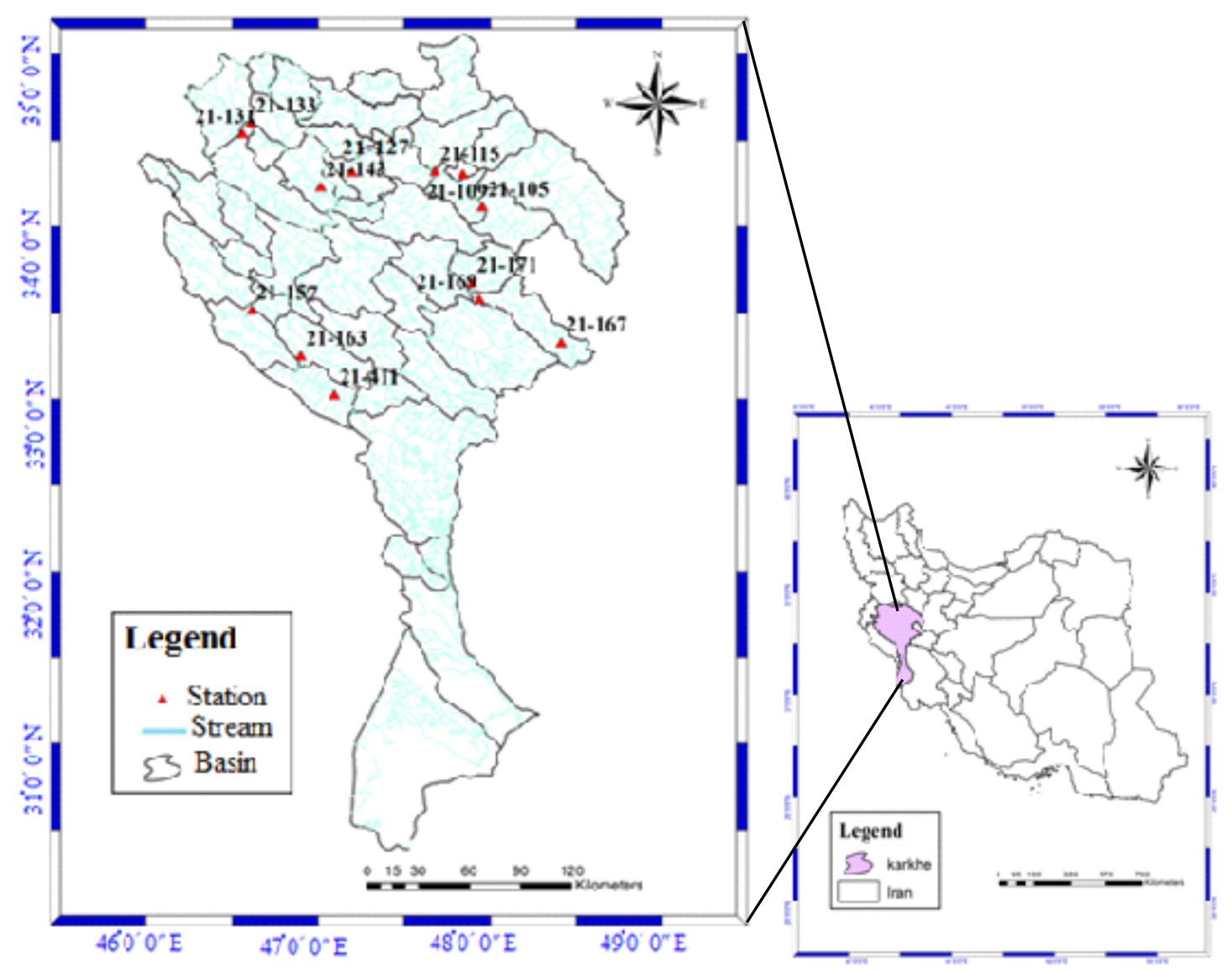

Fig.1: The location of study area and hydrometric stations

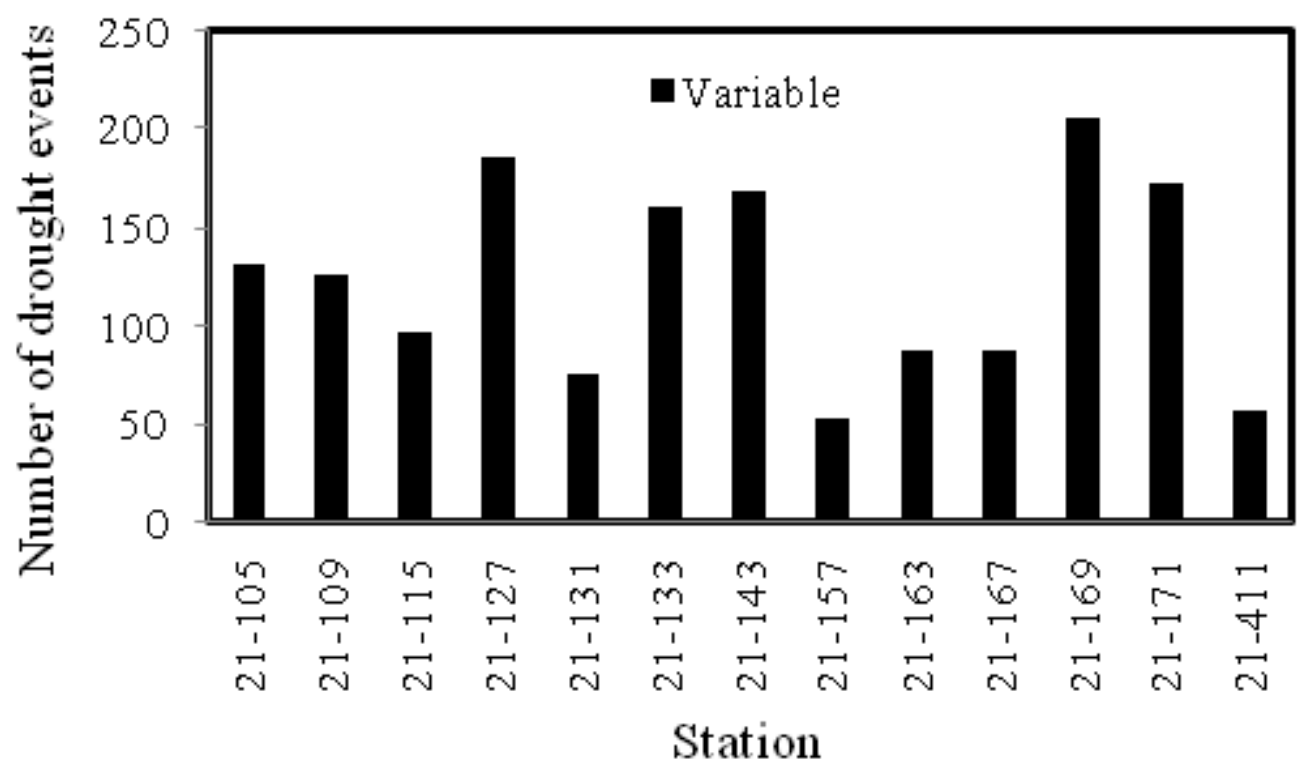

Fig. 2: Number of drought events during study period in all stations 
were related to Seymareh and Tang-siab stations, respectively. In addition the most and the least drought durations were related to Seymareh and Dehno stations (Figures 4 and 5). Since Seymareh station is located in downstream of the basin, its

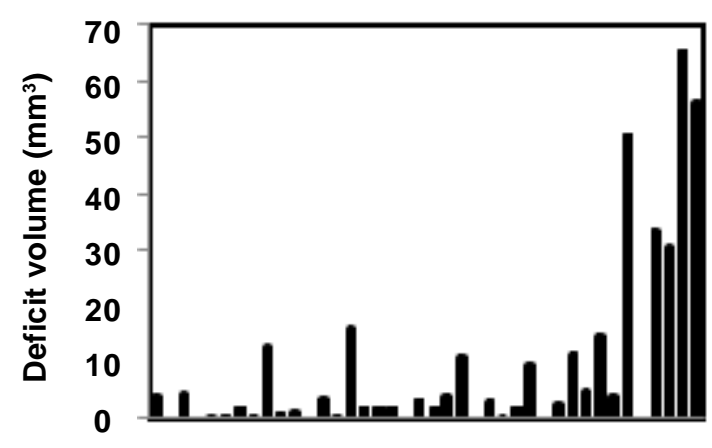

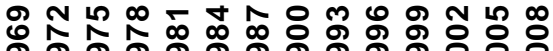

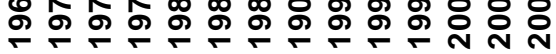

Time (Year)

Sangsurakh

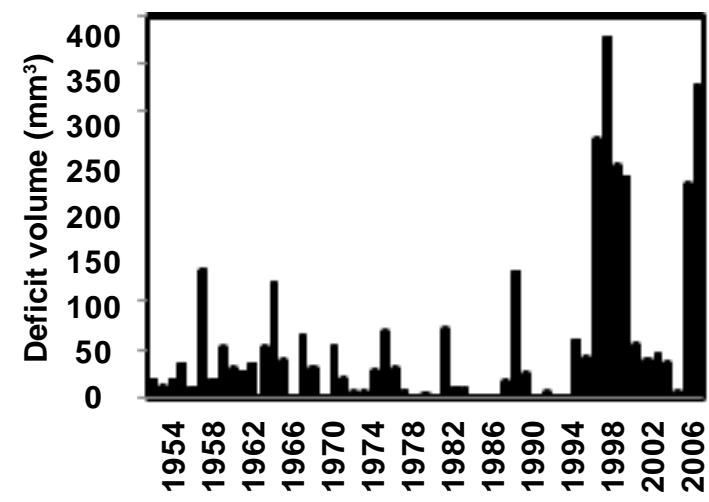

Time (Year)

Polechehr

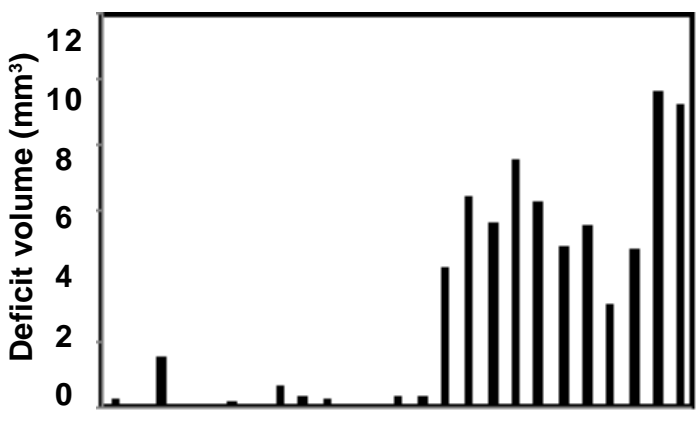

స ฒ

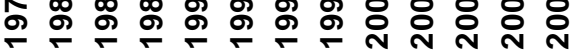
Time (Year)

Khersabad drought intensity is higher than upstream stations. In comparison with the upstream stations, downstream parts of the basin with associated problems such as water exploitation, water demanding for agricultural and industrial usages,
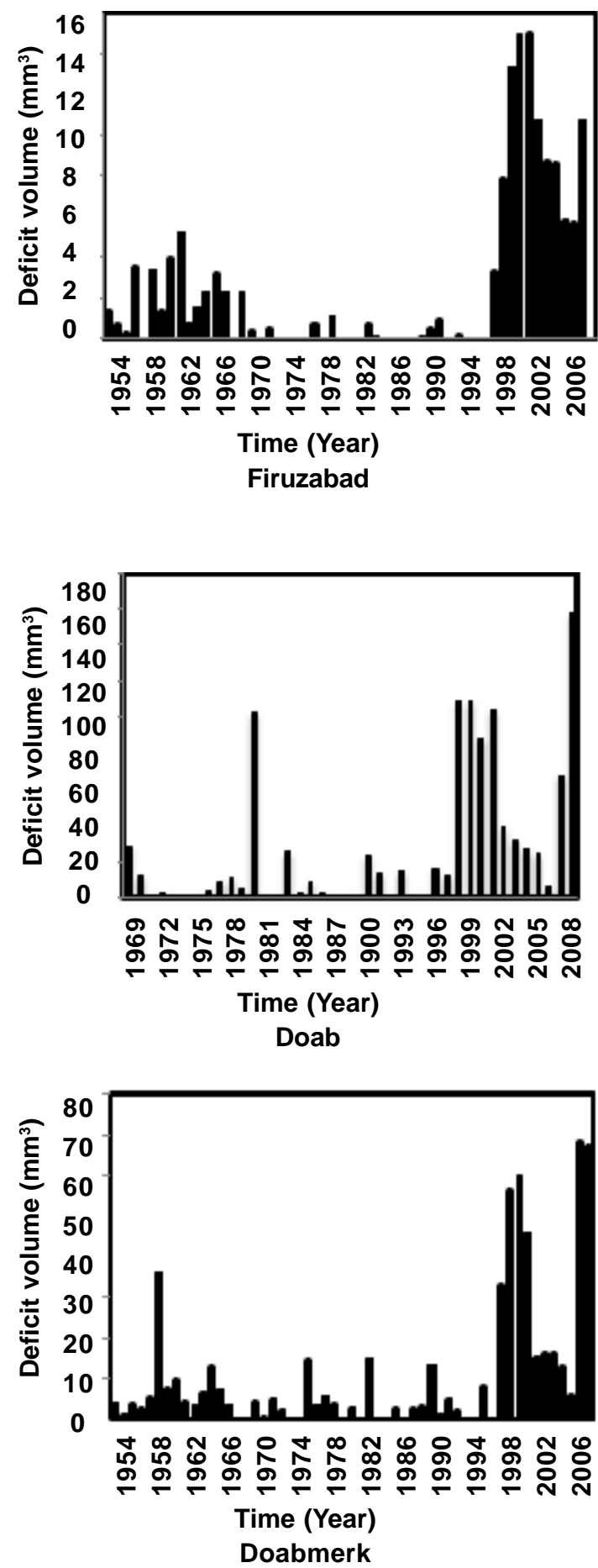
experience the occurrence of severe water scarcity (Asadi et al., 200925).

Generally results showed that the most deficit volume and the least drought duration in most
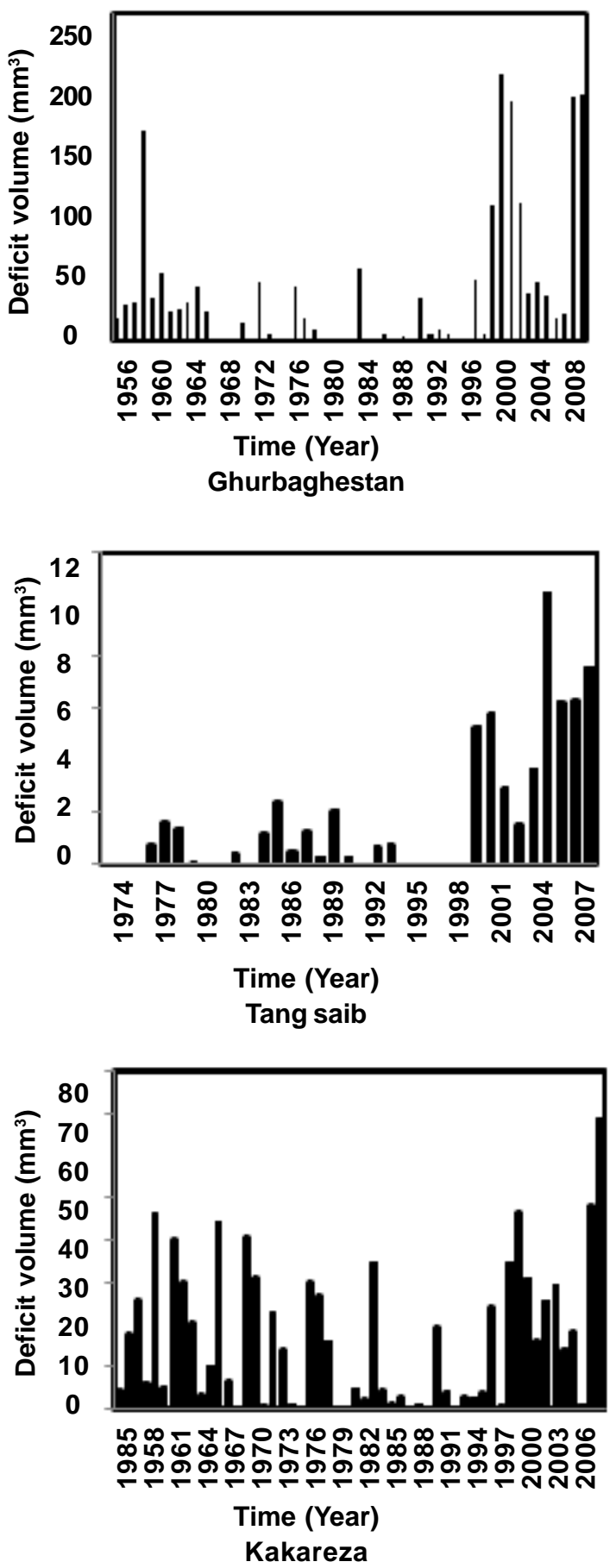

of the stations were occurred after 1998. In addition Asadi et al., (2009), Kariminazar et al., (2010) ${ }^{26}$ and Byzedi et al., (2012) ${ }^{27}$ presented this year as a dry year in their study.
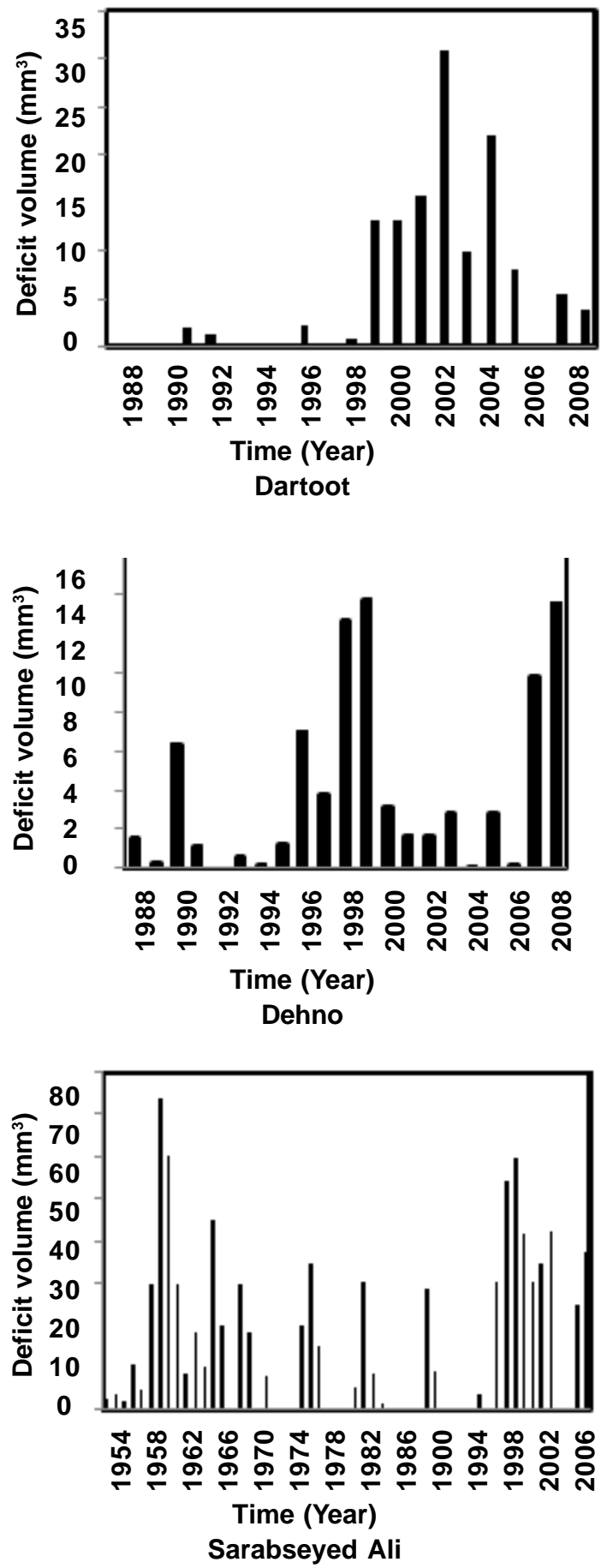


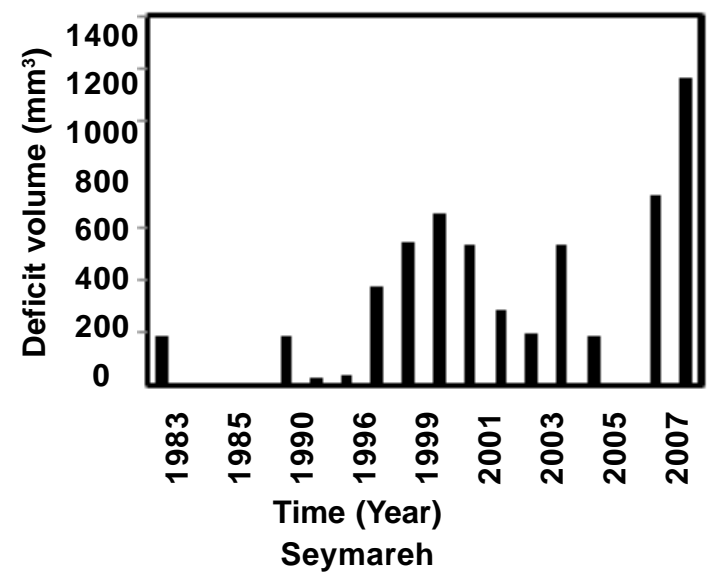

Fig. 3: Deficit volume during study period for threshold level $Q_{70}$ in all stations

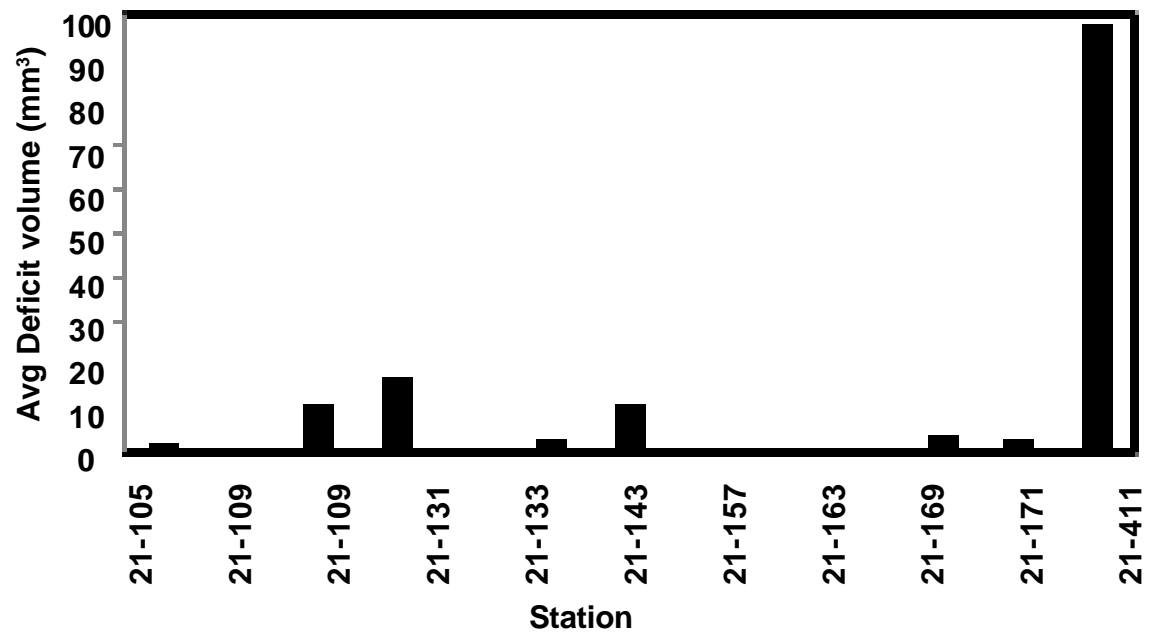

Fig. 4: Average deficit volume of hydrological drought in stations

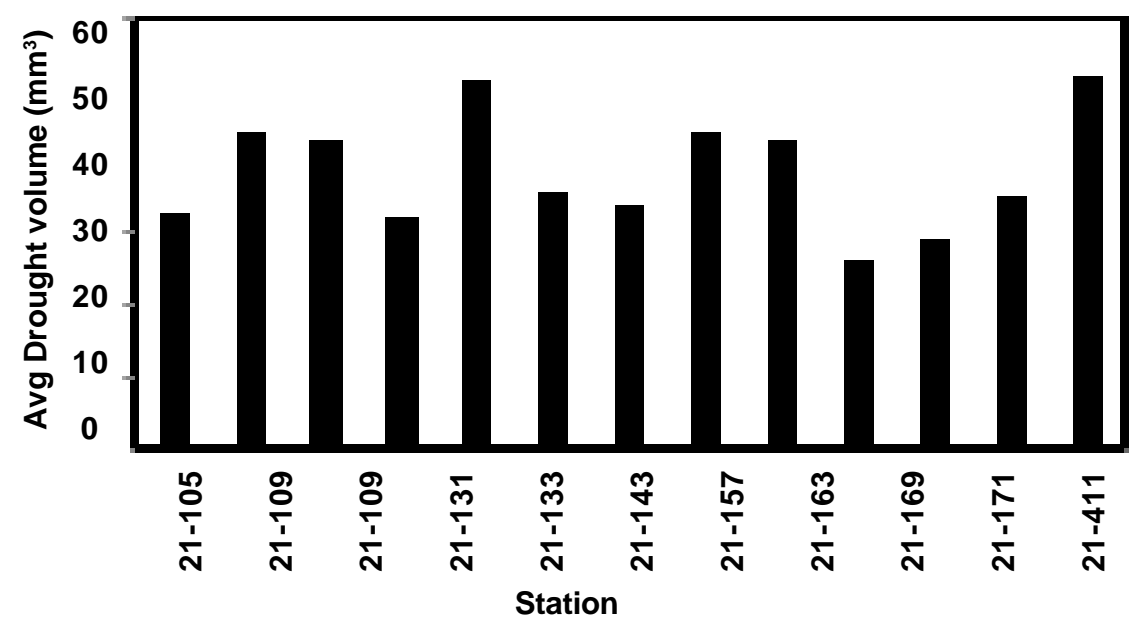

Fig. 5: Average drought duration of hydrological drought in stations 
The results indicated that the most drought periods were occurred in summer which sometimes lasted until mid-summer and even first days of fall. It seems that the main reason of river surface runoff reduction is the decrease in precipitation and in the following, increasing in the water demand. Yarahmadi (2009) ${ }^{28}$, Fleig et al., (2006) and Wong et al., (2011) reached to the same results as what is observed here.

As it was illustrated deficit volume and drought duration have somehow direct relationship with each other and their changing trend has the same direction. Also Byzedi (2009) ${ }^{29}$ showed the same results in his work.

According to the results of derived probability analysis of drought parameters and using variable threshold level method, suitable probability distributions for drought time series were determined in each station. Among all of the distributions, Weibull and GP for maximum series of deficit volume and GP distribution for maximum series of duration had the most fitness. Also Felig et al., (2006) achieved to the same results. According to this fact that the statistical distributions for deficit volume and drought duration are not necessarily the same in each station and based on two kinds of analysis, some differences were observed in return periods. The results showed that drought return period based on duration analyzing was more than return period of deficit volume in most of the years but their changing trend was the same (Table 3). The reason of this matter is that in some years, dry period with the most deficit volume had not the most duration, because in some years the drought period with maximum deficit volume had not maximum duration. Also Byzedi (2009) showed the same results in his work. Droughts with less intensity have more probable occurrence and less return period (Less than 5 and 10 years) (Hisdal and Tallaksen 2000).

According to the results it was observed that the stations in Karkheh River basin were not free from hydrological drought. So drought is a vital issue which should be considered and the results of hydrological drought analysis are useful for proper water resources management, better planning for water supply and demand.

\section{REFERENCES}

1. Samiei M., Saghafian B., Mahdavi M., Analysis Regional Hydrological Drought Severity in Tehran Province Watersheds, Journal of Natural Resources. 56(1): 27-39 (In Persian) (2006).

2. Khazaei M. R., Telvari A., Jabbari A., Frequency Analysis of Hydrological Drought (Case study; Gharehsou Watershed), Journal of Geography and Development. 1(2): 45-56 (In Persian) (2003).

3. Hisdal H., Tallaksen, L. M., Drought event definition. Technical Report to the ARIDE Project No.6: Supplement to Work Package 2 Hydro-meteorological Drought Activity 2.1 Event Definition, 1-41(2000).

4. Mishra A. K., Singh V. P., A review of drought concepts, Journal of Hydrology. 391(1-2): 202-216 (2010).

5. Van Loon A. F., Van Lanen H. A. J., A processbased typology of hydrological drought. Journal of Hydrology and Earth System Sciences, 16: 1915-1946 (2012).
6. Liu L., Hong Y., Bednarczyk C. N., Yong B., Shafer M. A., Riley R., Hocker J. E., Hydroclimatological drought analyses and projections using meteorological and hydrological drought indices: a case study in Blue River Basin, Oklahoma, Water resources management. 26: 2761-2779 (2012).

7. Choi M., Jacobs J. M., Anderson M. C., Bosch D. D., Evaluation of drought indices via remotely sensed data with hydrological variables, Journal of Hydrology. 476: 265273 (2013).

8. Vasiliades L., Loukas A., Liberis N. A., Water balance derived drought index for Pinios River Basin, Greece, Water resources Management. 25:1087-1101(2011).

9. Tallaksen L. M., Streamflow drought frequency analysis. In: Drought and Drought Mitigation in Europe (Ed. by Vogt J. V., Somma F.). Kluwer Academic Publishers the Netherlands.103-117 (2000). 
10. Bonacci O., Hydrological Identification of Drought, Hydrological Processes. 7: 249262 (1993).

11. Zelenhasic E., Salvai A., A Method of Streamflow Drought Analysis, Water Resources Research. 3(1):156-168 (1987).

12. Hisdal H., Tallaksen L. M., Frigessi A., Handling Non-Extreme Events in Extreme Value Modelling of Streamflow Droughts, in: FRIEND 2002 - Regional Hydrology: Bridging the Gap between Research and Practice, IAHS Publ. 274: 281-288 (2002).

13. Hisdal H., Tallaksen L. M., Clausen B., Peters E., Gustard A., Hydrological drought characteristics, in: Hydrological Drought. Processes and Estimation Methods for Streamflow and Groundwater, edited by: Tallaksen L. M., Van Lanen H., Developments in Water Science 48: Elsevier Science B.V, 139-198 (2004).

14. Engeland K., Hisdal H., Frigessi A., Practical Extreme Value Modeling of Hydrological Floods and Droughts: A Case Study, Extremes 7(1): 5-30 (2004).

15. Andreadis K. M., Clark E. A., Wood A. W., Hamlet A. F., Lettenmaier D.P., Twentiethcentury drought in the conterminous United States, Journal of Hydrometeorology . 6: 9851001(2005), doi:10.1175/JHM450.1.

16. Fleig A. K., Tallaksen L. M., Hisdal H., Demuth S. A., Global Evaluation of Streamflow Drought Characteristics, Journal of Hydrology and Earth System Sciences. 10: 535-552 (2006).

17. Tallaksen L. M., Hisdal H., van Lanen H. A. J., Space-time modelling of catchment scale drought characteristics. Journal of Hydrology, 375: 363-372 (2009).

18. Wong W. K., Beldring S., Engen-Skaugen T., Haddeland I., Hisdal H., Climate Change Effects on Spatiotemporal Patterns of Hydroclimatological Summer Droughts in Norway, Journal of Hydrometeorology. 12:1205-1220 (2011).

19. Vrochidou A. E. K., Tsanis I. K., Grillakis M. G., Koutroulis A. G., The impact of climate change on hydrometeorological droughts at a basin scale, Journal of Hydrology. 476: 290-301 (2013).

20. Giuntoli I., Renard B., Vidal J. P., Bard A.,
Low flows in France and their relationship to large-scale climate indices, Journal of Hydrology. 482: 105-118 (2013).

21. Tallaksen L. M., Madsen H., Clausen B., On the definition and modeling of stream flow drought duration and deficit volume, Hydrological Sciences Journal. 42(1): 1533(1997).

22. Fleig A., Hydrological Drought - A Comparative Study Using Daily Discharge Series from around World, M.Sc. Thesis. Institute fur Hydrologic, University Freiburg, Germany. 144 (2004).

23. Pandey R. P., Mishra S.K., Ramasastri K. S., Stream flow Drought Severity Analysis of Betwa River System (India), Water resources management. 22:1127-1141 (2008).

24. Shiau J. T., Fitting drought duration and severity with two-dimensional copulas, Water resources management. 20: 795-815 (2006). doi:10.1007/s11269-005-9008-9.

25. Asadi E., Mirabasi Najafabadi R., Malekpoor A., Fakherifard A., Dinpajou Y., Hydrological Drought Monitoring Using the Run Theory, (Case study; Aji-chai Watershed in East Part of Azerbaijan Province), The $2^{\text {nd }}$ National Conference on Drought Impacts and Management Strategies, Isfahan. (In Persian) (2009).

26. Kariminazar M., Moghadamnia A. R., Mosaedi A., Investigation of Climatic Factors Affecting Drought, Journal of Soil and Water Conservation Research. 17(1):145-158 (In Persian) (2010).

27. Byzedi M., Siosemardeh M., Rahimi A., Mohammadi K., Analysis of Hydrological Drought on Kurdistan Province, Australian Journal of Basic and Applied Sciences. 6(7): 255-259 ISSN 1991-8178 (2012).

28. Yarahmadi J., Frequency Analysis of Hydrological Drought in Gambarchay Watershed Using Model Series detail, The $2^{\text {nd }}$ National Conference on Drought Impacts and Management Strategies, Isfahan. 1-7 (In Persian) (2009).

29. Byzedi M., Saghafian B., Analysis of Hydrological Drought based on Daily Flow Series, The $2^{\text {nd }}$ National Conference on Drought Impacts and Management Strategies, Isfahan. (In Persian) (2009). 